\title{
Trappes: A visit to the heart of a community
}

Written by: Ileana Epsztajn, OECD Observer editor-at-large

Last update: 3 March 2020

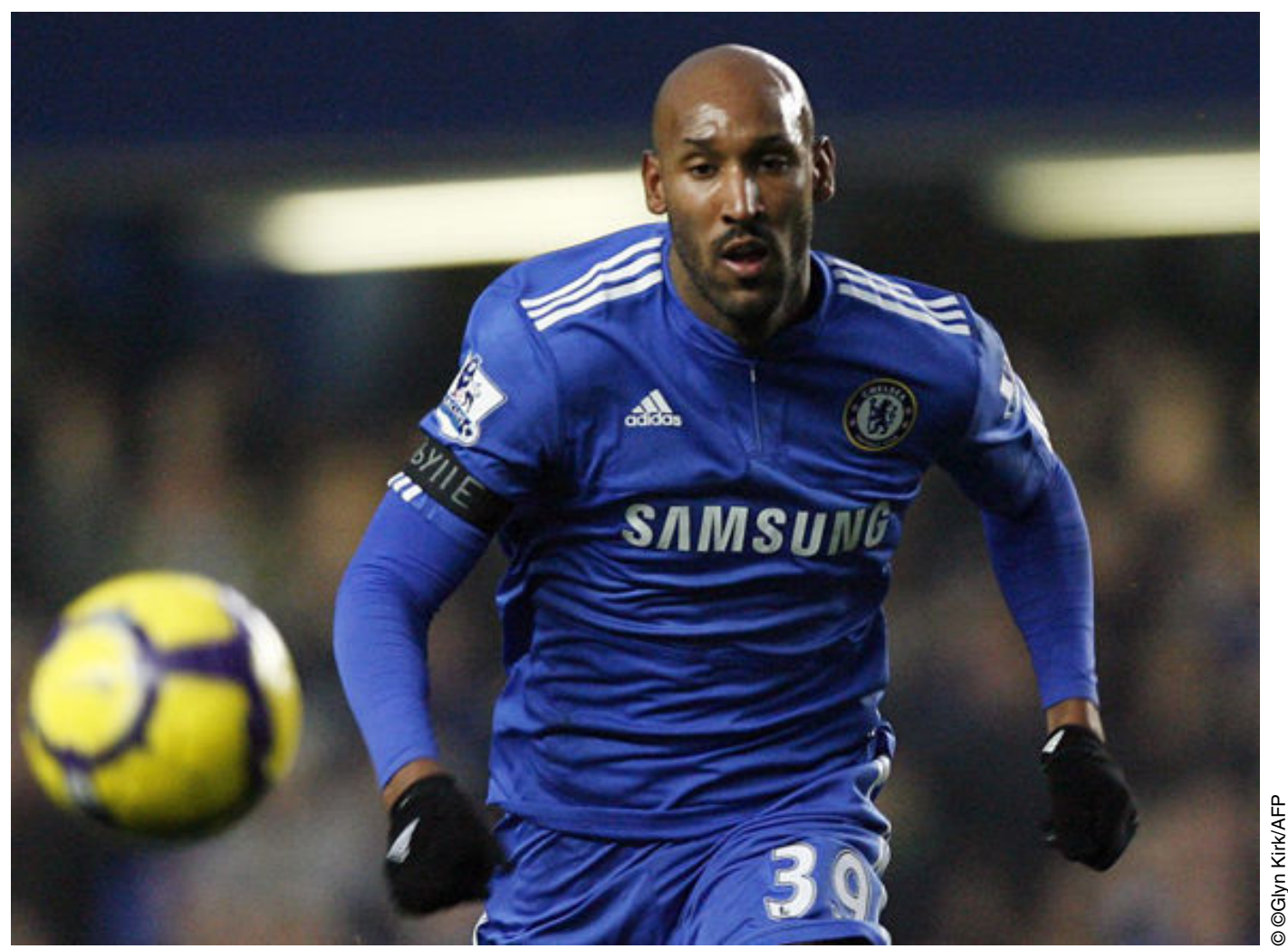

Trappes: A visit to the heart of a community I Nicolas Anelka, French footballer from Trappes

Some 25 kilometres from Paris lies Trappes, a town from which more people have left to fight in Syria than anywhere else in Europe. How did a town which has produced numerous French celebrities such as footballer Nicolas Anelka, comedian Jamel Debbouze, actor Omar Sy, and TV and radio presenter Sophia Aram, end up with this sad claim to fame?

This was one of the questions bothering Raphaëlle Bacqué, senior correspondent at Le Monde newspaper, and her colleague Ariane Chemin. So they decided to spend a year together in Trappes to try to understand the changes that had taken 
place within this community and to report their findings in a book*, which Raphaëlle Bacqué came to present at the OECD Forum.

The new residential areas built in Trappes in the 1960s were intended by the town council, run by the communist party since 1944, to fulfil its vision of an urban utopia made up of low-rise buildings and park areas that avoided the drawbacks of conventional suburbs. As the years went by, however, French families and those of Italian and Portuguese origin started to move out, and the proportion of new immigrants in the population rose by 325\% between 1968 and 1975. During the 1980s, delinquency went up as social diversity declined. And the following twenty years were marked by events which resulted in the town's retreat into itself and isolation. In the 1990s, the large secondary school attended both by children from Trappes and by those from rich neighbouring communes was joined by a second school to which all the pupils from middle-class and wealthy backgrounds gravitated. Then, at the start of the 2000s, a new, socialist mayor was elected on the promise of building a large mosque in Trappes. After years of efforts by the communist party to knit a social fabric, religion was intruding in the form of an Islamism close to that of the Muslim Brotherhood.

As a result, the social, economic and geographic community created by the town slipped into religious communalism. These days, as Raphaëlle Bacqué relates, the inhabitants of Trappes say "it's just us poor here". It is a commune which lives in proud isolation: nothing gets out (the author told how, for an entire year, the subject of her book, which was confidential, remained a secret, safe behind the hermetic barrier of the ring road around Paris) and nothing gets in. And for those who did get out, like the film stars and sports stars who grew up at a time when integration and assimilation were more readily accepted, it is difficult to come back given local resentment.

As Raphaëlle Bacqué says, "[Trappes] has been like a testing ground for all the experiments and failures of public policy in our suburbs". Or, as a resident of Trappes present at the Forum put it more bitterly, "if large numbers of young people from Trappes have gone to Syria, it's because public policies have forsaken the town".

*Raphä̈lle Bacqué and Ariane Chemin (2018), La Communauté, Éditions Albin Michel, Paris.

@OOECD Observer December 2018

\section{References}

Watch the OECD Forum: Meet the Author session with Raphaëlle Bacque (in French): https://www.youtube.com/watch?v=Enkz61h3DY4 https:// www.youtube.com/watch?v=Enkz61h3DY4

OECD work on regional, rural and urban development: www.oecd.org/regional/ www.oecd.org/regional/ 